\title{
流域スケールの雨水貯留量推定法の 理論的修正とその効果 \\ REVISION OF ESTIMATION METHOD OF WATERSHED-SCALE RAINWATER STORAGE AND ITS EFFECT
}

\author{
千葉宇彦 1 横尾善之 2 \\ Takahiko CHIBA and Yoshiyuki YOKOO \\ 1非会員＼cjkstart福島大学学生 共生システム理工学類（†960-1296 福島市金谷川1） \\ 2正会員 博（工） 福島大学准教授 共生システム理工学類（†960-1296 福島市金谷川1）
}

\begin{abstract}
This study attempted to improve a methodology for estimating watershed-scale storage changes from hourly discharge data and to verify its effect in the upper Abukuma River watershed in Japan. The previous methodology separate hydrographs into several discharge sub-components by a filter-separation method, and then it explored relationships between discharge sub-component $Q$ and watershed-scale storage $S$, assuming power-law relationships between derivative of discharge sub-components $\mathrm{d} Q / \mathrm{d} t$ and $Q$. The present study employed linear relationships between $Q$ and $S$ to be theoretically consistent with the filter-separation method in which linear relationships are assumed between $Q$ and $S$. Based on this theoretical revision, we re-estimated watershed-scale storages to compare with those estimated by the previous methodology. As the result, we found instantaneous increases of storage after rainfall events become smaller and storage change become smoother. In addition, we confirmed the present methodology can estimates more realistic storage than previous one in terms of event-scale water balance.
\end{abstract}

Key Words : recession analysis, hydrograph separation, discharge, Abukuma River

\section{1. 序論}

本研究は，地表水，地下水，土壤水分，表土の水や積 雪などをすべて含めた流域内の単位面積あたりの水量の うち，最終的に河川流量観測点を通過するものを「雨水 貯留量」と定義し，その推定法を議論する．流域スケー ルの雨水貯留量は直接的に測定することが非常に困難で あるため，流域スケールの水収支式から推定されてきた 1)-3). この場合，降水量から蒸発散量および流量を差し 引いた残差として貯留変動を求め, これにある基準面か らの高さを加算することで貯留高に変換する. しかし, 流域スケールの蒸発散量も直接的に計測することができ ないため, 推定する他はない，一方，高精度の重力計測 器を用いて貯留変動の推定が行われた例があるが，コス 卜と技術面に課題があり，流域スケールの推定は難しい とされている4-5.

この問題を解決できる手法としてKirchner ${ }^{6)}$ は意外な 方法論を紹介している. Kirchner ${ }^{6}$ は, 出水後の夜間無降 雨の期間であれば流域スケールの水収支のうち降水量と
蒸発散量が無視でき, 流出高から貯留高の変化を直接計 算し，貯留高を積分することである基準面からの高さと して貯留高を計算できることを示している．この手法は， 貯留・流量関係が単一の関係式で近似できる比較的単純 な降雨流出過程の流域ならば適用できる。しかし，日本 流域は降雨流出過程が複雑であり，この手法を直接適用 すると貯留高の推定值が不自然な変動を示すことを横尾 ら`は示している. Kirchner のの手法の改良は他にも提案 されており, 例えばTeuling et $\mathrm{al} .{ }^{8}{ }^{8}$ は貯留変化と流量の関 係を，流量の大きさによって場合分けして別々に決定す

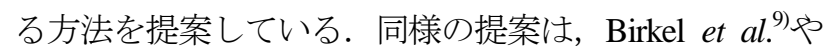
Krakauer and Temimi ${ }^{10)}$ 等によっても行われているが，こ れらの手法では貯留量や流量が季節変化する流域では適 用するのが困難であるとMcMillan et al. ${ }^{11)}$ は指摘している. この問題に対しKobayashi and Yokoo ${ }^{12}$ 怯, 日野・長谷 部 $^{13)}$ の成分分離手法を用いて流量データを成分分離した

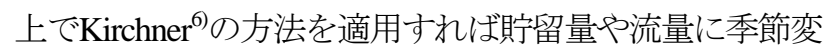
化がある流域においても貯留高を良好に推定できること を示している. この手法を用いて土砂災害の発生と流域 の雨水貯留高の関係を検討した研究も行われている ${ }^{14-15)}$. 


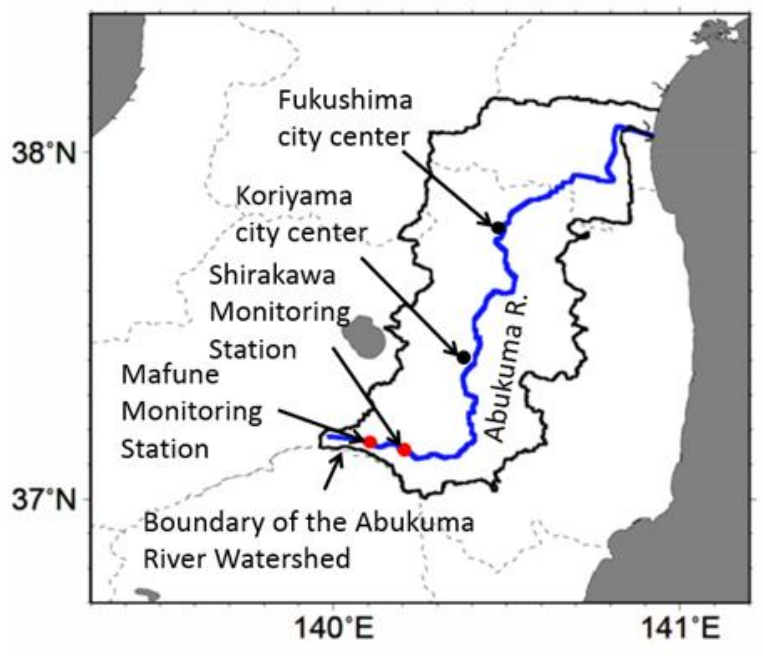

図-1＼cjkstart対象流域の位置図

しかし, Kobayashi and Yokoo ${ }^{12)} の$ 手法は, 貯留高と流出 高の関係が線形であることを仮定した成分分離の結果に， その関係が非線形であることを仮定したKirchner ${ }^{6}$ の貯留 量推定の式を組み合わせる点に論理的な不整合がある. そこで本研究は，貯留量と流量の非線形な関係を線形な 関係に変更して論理的な不整合を取り除いた上で線形化 の影響を確認し，線形化の有効性を示す.

\section{2. 方法}

\section{（1）対象流域および使用データ}

本研究は一級河川の阿武隈川の白河流量観測所の流域 を対象とした（図-1）。国土交通省の水文水質データ ベース（http://www1.river.go.jp/）から，白河流量観測所 の毎時の流量データおよび真船雨量観測所の毎時の雨量 データを2005〜2007年の期間について取得した.

\section{（2）流量の成分分離手法}

日野・長谷部 ${ }^{13)}$ が提案した成分分離手法では，まず流 出高データを片対数プロットし，流出高の逢減部から傾 きの異なる複数の逈減部を特定する. 次に, この逢減部 に指数関数をあてはめて聥減係数を決定し，この逓減係 数の逆数である時定数 $T_{c}$ を求める. ここで得られた $T_{c}$ を 式(1)-(2)に代入する。

$$
\begin{aligned}
& c_{0}=\left(\delta / T_{c}\right)^{2} \\
& c_{1}=\delta^{2} / T_{c}
\end{aligned}
$$

ただし，本研究ではTcは小数点以下を四捨五入した整数 とし， $\delta$ は2.1に固定している. なお， $\delta$ の值が本研究の 成分分離結果にほとんど影響しないことは事前に確認し ている.

数值フィルターの核となる $\omega$ は次式で与える. $\omega(\tau)= \begin{cases}c_{0} \exp \left(-\frac{c_{1} \tau}{2}\right) \sinh \left(\sqrt{\frac{c_{1}^{2}}{4}-c_{0}} \cdot \tau\right) / \sqrt{\frac{c_{1}^{2}}{4}-c_{0}} & (\tau>0) \\ 0 & (\tau \leq 0)\end{cases}$

式中の $\tau$ は数值フィルターの開始からの経過時間を示す. この式を次式に代入して遅い流出成分 $Q$ 'を分離する.

$$
Q^{\prime}(t)=\alpha \sum_{\tau=0}^{k} \omega(\tau) Q(t-\tau)
$$

成分分離前の流出高 $Q$ から分離後の流出高 $Q$ '差し引い て求めた残りの流出高が負とならないように式(4)を用い て成分分離するすべての成分において重み係数 $\alpha を 0.1<\alpha$ $<1 の$ 範囲で設定した. 本研究はKobayashi and Yokoo ${ }^{12)}$ に ならい, $k$ は成分ごとに異なる $T_{\mathrm{c}}$ の5倍の值 $\left(k=5 T_{\mathrm{c}}\right)$ とし た. 成分分離には日野・長谷部の手法 ${ }^{13)}$ を利用したが, 分離する成分数の決定には解析者の裁量がどうしても反 映されてしまう。この点については，西山・横尾 ${ }^{16)}$ を参 考に河川流量の聥減時定数 $T \mathrm{c}$ の対数 $\log _{5} T \mathrm{c}$ を四捨五入し た整数が変化したら降雨流出過程が変化したと仮定して 主要成分数を同定する方法を採用した。これにより，本 研究では，河川流量の逢減部の違いから，この成分分離 を $T_{\mathrm{c}}$ の大きいものから順に4回あてはめ，5成分に流量を 分離した. ただし, 河川流量の観測点を通過しない地下 水は流動経路に関わらず無視しているため, 流域内に存 在するすべての降雨流出過程を表現している訳ではない.

\section{（3）貯留高の推定方法}

Kobayashi and Yokoo ${ }^{12)}$ が用いたKirchner ${ }^{6}$ の手法の概略 を説明する.まず式(5)で示す流域スケールの水収支式を 式(6)のように代入し, 貯留高と流出高の関係を導く.

$$
d S / d t=P-E T-Q
$$

$$
\frac{d Q}{d S}=\frac{d Q / d t}{d S / d t}=\frac{d Q / d t}{P-E T-Q}
$$

式(6)は夜間・無降雨のときのように，降雨量と蒸発散量 が流量よりもはるかに小さく, 降雨と蒸発散量を無視で きる場合，貯留高と流出高の関係は式(7)のように近似す ることができる.

$$
g(Q)=\frac{d Q}{d S} \approx \frac{d Q / d t}{-Q}_{P \ll Q, E T \ll Q}
$$

これにより，流域スケールの貯留高と流出高の関係が流 量データのみから決定できる．なお，本研究では夜の19 時から翌日の朝の6時までを夜間と定義した，Kirchner ${ }^{6}$

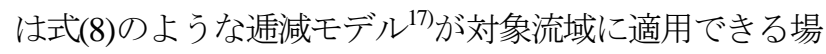
合, 式(7)と式(8)から式(9)の関係が導けるとしている.

$$
\mathrm{d} Q / \mathrm{d} t=-a Q^{b}
$$




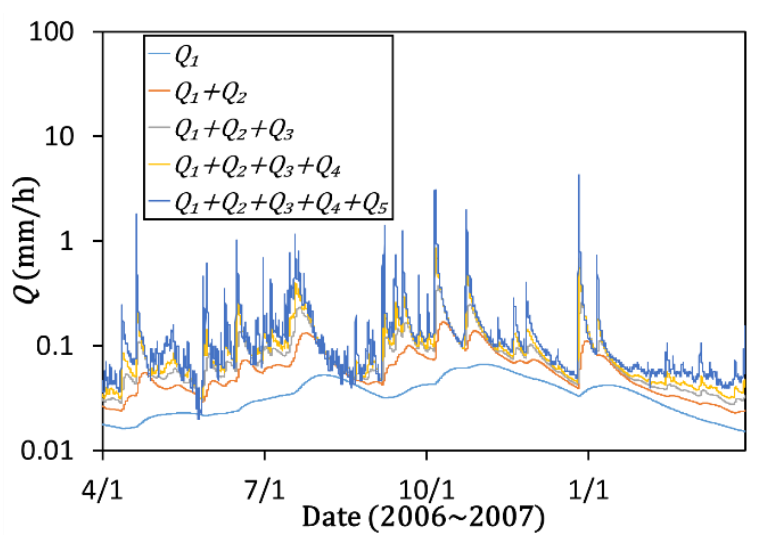

図-2 成分分離結果の一部

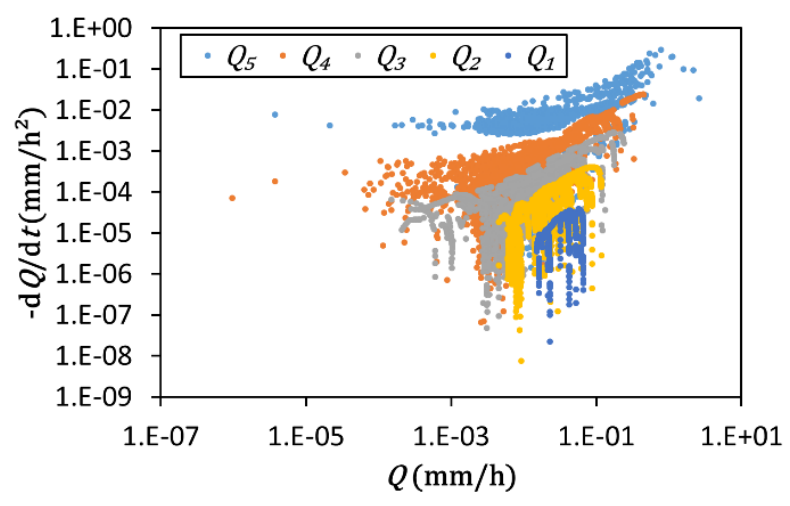

図-3 各成分における流出高と流出高変動量の関係

\begin{tabular}{lcc}
\multicolumn{3}{c}{ 表-1 利用したパラメータ } \\
\hline & Kobayashi \& Yokoo (2013) & 本研究 \\
\hline$Q_{1}$ & $a=0.0005, b=1.05$ & $a=0.0005$ \\
$Q_{2}$ & $a=0.0111, b=1.48$ & $a=0.0030$ \\
$Q_{3}$ & $a=0.0093, b=1.08$ & $a=0.0109$ \\
$Q_{4}$ & $a=0.0129, b=0.86$ & $a=0.0462$ \\
$Q_{5}$ (線形) & & $a=0.1064$ \\
$Q_{5}$ (非線形) & $a=0.0171, b=0.52$ & $a=0.0171$ \\
& & $b=0.52$ \\
\hline
\end{tabular}

$$
\int d S=\int \frac{d Q}{g(Q)}=\int \frac{1}{a} Q^{1-b} d Q
$$

この式(9)の積分を行うと，式(10)のように貯留高を計算 することができる.なお， $a, b$ はパラメータである.

$$
S-S_{0}=\frac{1}{a} \frac{1}{2-b} Q^{2-b}
$$

ここで， $S_{0}$ は積分定数であるため，流域スケールの貯留 高の絶対值はある基準面からの高さとして算出される.

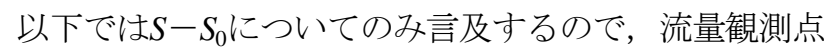
を通過しない雨水貯留高は無視していることになる.

本研究は式(8)-(10)のbを1とした式(11)の線形モデルを 新たに仮定する.これは, 式(12)のような指数関数モデ ルで莪減部を表現することに相当する.

$$
\begin{gathered}
-d Q / d t=a Q \\
Q=Q_{0} \cdot \exp (-a t)
\end{gathered}
$$

これにより，日野・長谷部 ${ }^{13)}$ のイルター分離手法との 論理的整合性が保持される. パラメータ た各成分に対して $-\mathrm{d} Q / \mathrm{d} t$ と $Q$ の関係を図示し，その関係 を式(11)で近似することで決定した.

\section{3. 結果}

\section{（1）流出高Qと流出高変動 $-\mathrm{d} Q / \mathrm{d}$ tの関係}

図-2の上うに成分分離した各成分のうち夜間・無降雨 時の流量聥減部のデータを用いて流出高 $Q$ と流出高減少 量 - $\mathrm{d} Q / \mathrm{d} t$ 関係をまとめたのが図-3である. 成分分離し た各成分に時定数が大きい順に添字の1から4を付したた め, 図中の $Q_{1}$ が最も遅い成分であり, $Q_{5}$ が最も速い成分 である．Kirchner) と同様に両者の関係は累乗モデルや線 形モデルで近似できるものの, データのばらつきが大き いことが分かる．また，基底流 $Q_{1}$ のように遅い成分ほど $-\mathrm{d} Q / \mathrm{d} t$ の変動幅に比べて $Q$ の変動幅が小さく, 一つの回 帰モデルで両者の関係を説明できる度合いが低下寸るこ とが分かる。

本研究は，図-3の関係に線形近似をあてはめて式(11) のパラメータ $a$ を成分別に決定した. また， $Q_{5}$ にいて はKobayashi and Yokoo ${ }^{12)}$ の手法で用いられた式(8)の結果 と本研究で用いた式(11)の結果を比較するためにパラ メータ $a, b$ の值も累乗近似で求めた. 決定したパラメー 夕はKobayashi and Yokoo ${ }^{12)}$ 手法で求めたパラメータと ともに表-1にまとめた.

\section{(2) Kobayashi and Yokoo ${ }^{12)}$ と本研究の比較}

Kobayashi and Yokoo ${ }^{12}$ は貯留高と流出高の関係に非線 形モデルを仮定しているが，本研究ではすべての成分に 線形モデルを仮定して貯留高の推定を行った. 図-4〜図 -8は, Kobayashi and Yokoo ${ }^{12}$ の手法で得られた貯留高と 本研究で得られた貯留高を日中や降水時を含めて比較し たものである。この図から全ての成分において， Kobayashi and Yokoo ${ }^{12)}$ の值が高いことがわかる. また分 離時定数の小さい成分になるにつれ貯留高の本研究と既 存研究の結果の差が相対的に大きくなり $S_{5}-S_{05}$ では顕著 に差が現れている.

\section{（3）貯留量推定における線形と非線形の比較}

本研究は, 貯留高と流出高の関係に線形モデルを仮定 することで, 同じく線形モデルを仮定するフィルター分 離法 ${ }^{13)}$ との論理的整合性の維持を狙っている.このため, 式(7)から流出高と流出高変動の関係にも線形モデルを仮 定している. しかし，最後の成分分離を行った際の残流 量である $Q_{5}$ に限っては数值フィルターを通していないた め, 流出高と流出高変動の関係に線形と非線形のどちら のモデルを採用しても論理的な不整合はない，そこで， $Q_{5}$ におけるパラメータは, 線形と非線形の両方のモデル 


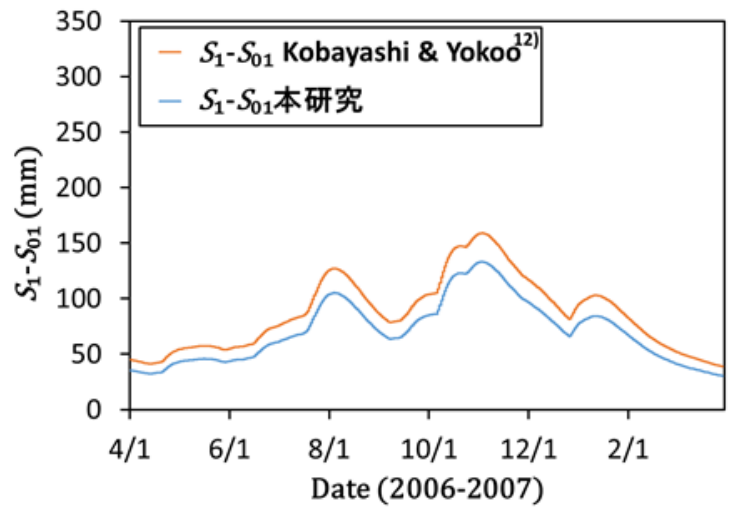

図-4 本研究と Kobayashi and Yokoo ${ }^{121}$ の貯留高の推定値 $S_{1}-S_{01}$ の比較

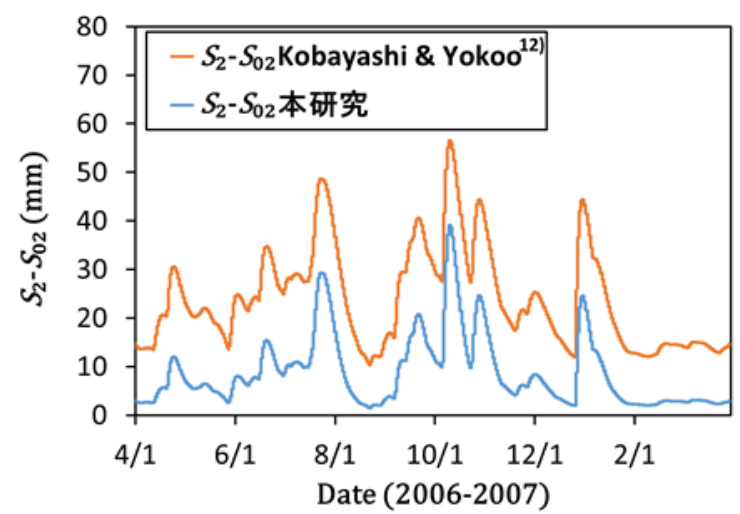

図-5 本研究と Kobayashi and Yokoo ${ }^{12)}$ の貯留高の推定値 $S_{2}-S_{02}$ の比較

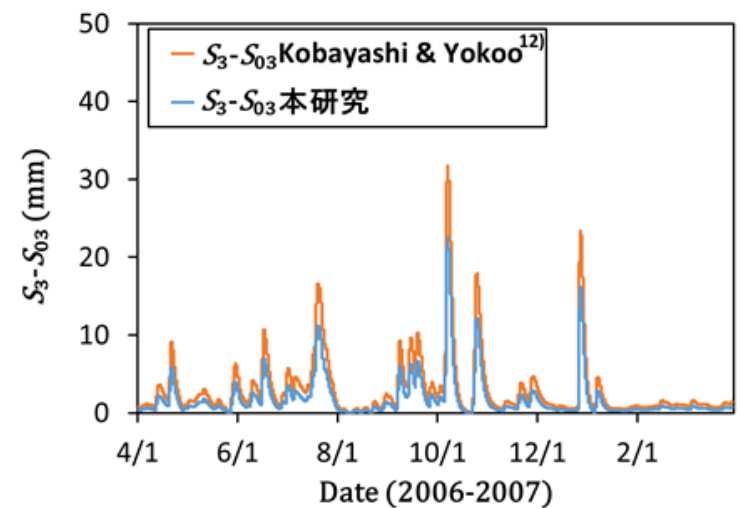

図-6 本研究と Kobayashi and Yokoo ${ }^{12)}$ の貯留高の推定値 $S_{3}-S_{03}$ の比較

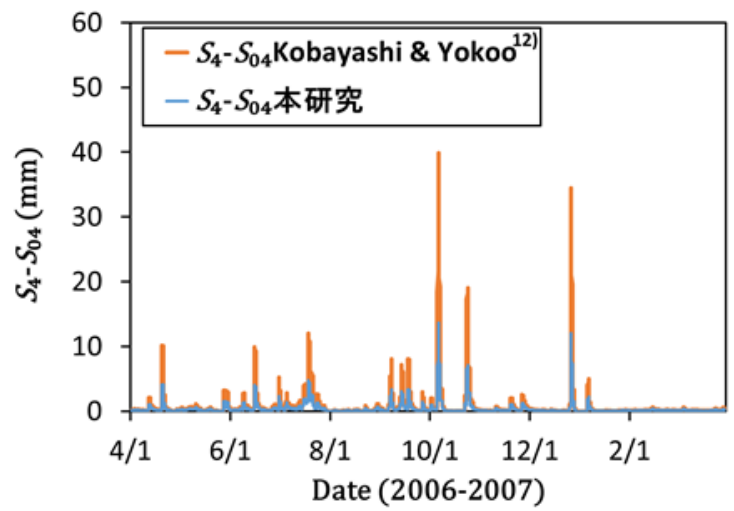

図-7 本研究と Kobayashi and Yokoo ${ }^{12)}$ の貯留高の推定値 $S_{4}-S_{04}$ の比較

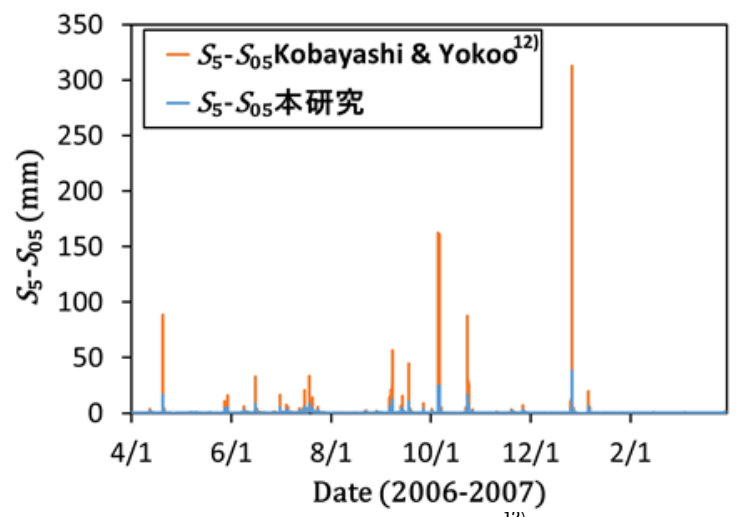

図-8 本研究と Kobayashi and Yokoo ${ }^{12)}$ の貯留高の推定値 $S_{5}-S_{05}$ の比較
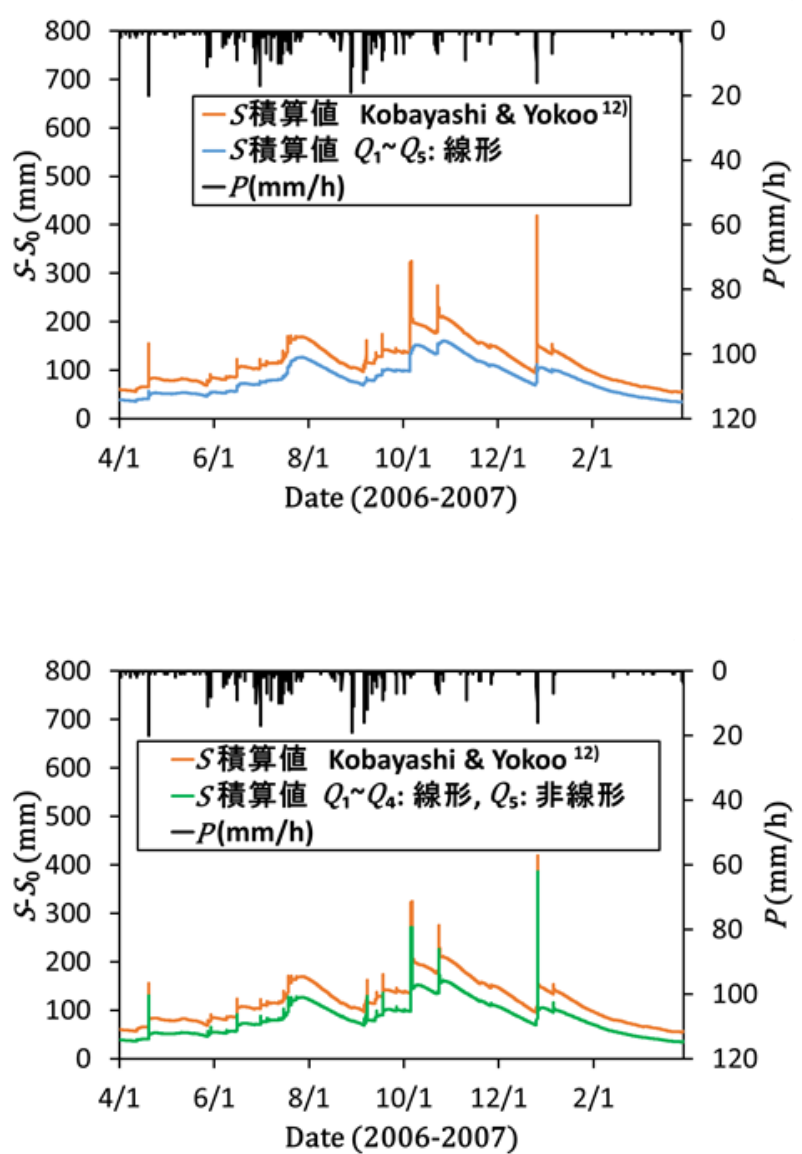

図-10 Kobayashi and Yokoo ${ }^{12)}$ の手法での結果とQ5のみを 非線形モデルを適用して計算した貯留高積算値

を用いて貯留高の推定結果を比較した結果を図-9（全て 線形）と図-10（ $Q_{5}$ のみ非線形）に示す. 両図とも, Kobayashi and Yokoo ${ }^{12)} の$ 手法による貯留量の推定值を比 較のために併記した。 これらの図から，いずれの手法で も貯留量の季節的変動が確認できるが，Kobayashi and Yokoo $^{12)}$ の手法よりも本研究の值が一貫して低くなる傾 向があることが分かる。さらに $Q_{5}$ に線形と非線形のモデ ルをあてはめた本研究の結果を比較すると, 線形モデル では降雨による瞬間的な貯留高の大きな上昇は確認でき ないが，非線形モデルではそれが確認できる. 


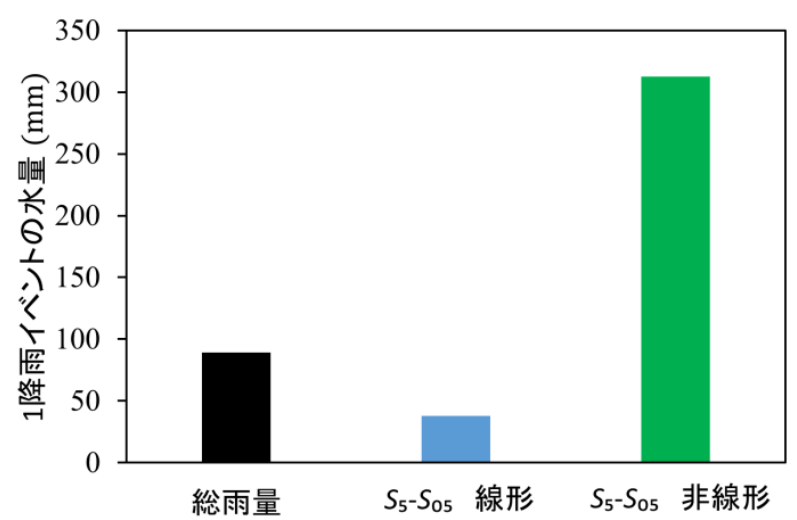

図-11 2006/12/26 9:00 2006 / 12/27 5:00 の期間の総雨量お よび線形モデルと非線形モデルを適用して求めた貯留量 $S_{5}-S_{05}$ の変動量

本研究はさらに $Q_{5}$ の貯留量の推定に用いるモデルとし ての線形モデルと非線形モデルの優劣を判断するため, 1降雨イベントの水収支を計算した．対象としたのは, 2006/12/26 9:00に開始し，2006/12/27 6:00に終了した降雨 イベントである. この期間に対象期間中に最も大きく $Q_{5}$ の貯留高が上昇している. 貯留高の推定值が最大になっ たのは両モデルともに 2006/12/27 5:00 であった. そこ で降雨発生時から貯留高の推定值が最大になるまでの貯 留高の変動量とその期間の総雨量を比較した（図-11）。 この図より線形モデルで $S_{5}-S_{05}$ を求めた場合の貯留高の 変動量は総雨量 $(\mathrm{mm})$ よりも少なくなり, 非線形モデル で $S_{5}-S_{05}$ を求めた場合は貯留量の変動量が総雨量よりも 約3倍大きいことが分かった．総雨量よりも貯留量の変 動量の方が大きいということは水収支的には整合性が維 持されないため， $Q_{5}$ に対しても線形モデルを適用寸る方 がよいと考えられる.

\section{4. 考察}

本研究は, Kobayashi and Yokoo ${ }^{12)}$ が日野・長谷部13)の 成分分離法と Kirchner6)の理論を組み合わせて提案した 雨水貯留量推定法における理論的な不整合を取り除き, その有効性を示したが，まだ課題が残されている.

まず，本研究では貯留高の推定值の妥当性についての 直接的な検討は行っていない. しかし，この点について は本研究と類似した手法を採用したYokoo et al. ${ }^{14)}$ や小 林・横尾 ${ }^{15}$ が，流出高と流出高変動の関係に非線形モデ ルを仮定したものの, Ishihara and Kobatake ${ }^{18)}$ のンクモ デル構築法を基礎とした土壤雨量指数 ${ }^{19)}$ と流域スケール の雨水貯留高の推定值との比較を行い, 貯留高の值と土 砂災害との明確な関係性を見出している.このため，本 研究の推定值も土壌雨量指数とよく対応し, 土砂災害の 関係性を議論できる程度にはその妥当性があると考えら れる. さらに妥当性を追求するには，対象とする空間ス ケールは大きくなるものの，現地観測による貯留量変動
45)の推定值と比較することも必要かもしれない. しかし， それにはまず世界の主要河川流域の空間スケールでの雨 水貯留量を推定する方法論を検討する必要がある.

さらに, Milly ${ }^{20)}$ のうに気候条件と降雨流出プロセス の貯留量の関係, Bishop et al. ${ }^{21)}$ のうに地質と貯留量の 関係, Soulsby et al. ${ }^{22}$ のように現地観測による雨水の滞留 時間と貯留量の関係, MacDonald et al. ${ }^{23)}$ のような既存の 貯留量の空間分布の推定值との関係などについて検討で きれば，貯留・流出プロセスの解明と貯留高の定量的把 握をより一層深めることができると考えている.

上述のように, 本研究が改良した流域スケールの雨水 貯留量の推定法にはまだ課題が残されているが，“河川 流量データに基づく主要な降雨流出過程のモデリング手 法”としては大きな可能性を秘めているのではないだろ うか. 観測データに基づくモデル構築法の重要性は解か れている ${ }^{24}$ が, 流量データから流域内の降雨流出過程を ここまで表現できる方法は見当たらない，特に，西山・ 横尾 ${ }^{10}$ の考え方を参考に, 流量データの瓜減時定数の対 数を利用して降雨流出過程の切り替わりを客観的に特定 できる点は，未だ解決されていない “主要なプロセス” の特定方法 ${ }^{25}$ としても非常に有効であると考えられ，今 後の発展が期待できる.

\section{5. 結論}

本研究は，賍留量と流量の関係に線形モデルを仮定す る日野・長谷部 ${ }^{13)}$ の成分分離法から得られた各流出成分 に，その関係に非線形 (累乗) モデルを仮定している Kirchner ${ }^{6}$ の手法をあてはめることで流域スケールの雨水 貯留高を推定しているKobayashi and Yokoo ${ }^{12)}$ の方法論の 論理的な不整合（線形モデルを仮定した成分分離結果に 非線形モデルをあてはめること）の改善法を検討した. 具体的には，貯留高と流出高の関係に線形モデルをあて はめて論理的不整合を取り除き, 貯留高の推定結果の妥 当性を検討した. ただし，論理的には線形モデルを仮定 する必要がない最も降雨に対する応答が速い成分につい

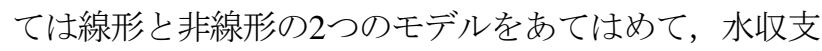
の観点からどちらのモデルがよいかについても検討を 行った. その結果, 最も降雨に対する応答が速い成分を 含めてす心゙て線形モデルをあてはめる方が良いとの結論 に至った. しかし, 論理的不整合の除去とその影響評価 に検討の重点を置いたため, どんな場合にもすべての成 分に線形モデルをあてはめるべきかとの問いに対する答 えを導くには至っていない，また，本研究で検討した手 法にはまだいくつかの課題が残されていることを議論し た. 今後は, これらの課題についての検討を進める必要 があると考えられる.

謝辞 : 科学研究費補助金（若手研究B，24760388），環 
境省環境研究総合推進費S-8-1(4), JST/CREST「安全で 持続可能な水利用のための放射性物質移流拡散シミュ レータの開発」の成果の一部である.また，本研究は国 土交通省の水文水質データベース，数值地図情報を活用 した.ここに謝意を記す。

\section{参考文献}

1) Norman, E.P.: Water storage at the Panola Mountain Research Watershed, Georgia, USA, Hydrol. Process., Vol.25, pp.38783889, doi: 10.1002/hyp.8334, 2011.

2) Sayama, T., McDonnell, J.J., Dhakal, A. and Sullivan, K.: How much water can a watershed store?, Hydrol. Process., Vol.25, pp.3899-3908, doi: 10.1002/hyp.8288, 2011.

3) Birkel, C., Soulsby, C. and Tetzlaff, D: Modelling catchment-scale water storage dynamics: reconciling dynamic storage with tracerinferred passive storage, Hydrol. Process., Vol.25, pp.3924-3936, doi: 10.1002/hyp.8201, 2011.

4) Creutzfeldt, B., Ferré, T., Troch, P., Merz, B., Wziontek, H., and Güntner A.: Total water storage dynamics in response to climate variability and extremes: Inference from long-term terrestrial gravity measurement, J. Geophys. Res., 117, D08112, doi:10.1029/2011JD016472, 2012

5) Benjamin, C., Peter A. T., Andreas G., Ty P. A. F., Thomas, G. and Bruno, M.: Storage-discharge relationships at different catchment scales based on local high-precision gravimetry, Hydrol. Process., doi: 10.1002/hyp.9689, 2013.

6) Kirchner, J.W.: Catchments as simple dynamical systems: Catchment characterization, rainfall-runoff modeling, and doing hydrology backward, Water Resour. Res., Vol.45, W02429, doi: 10.1029/2008WR006912, 2009.

7) 横尾善之, 小林秀平, 川崎雅俊 : 日本の山地流域における 貯留量变化および貯留能の推定に向けた基礎的検討，土木 学会論文集 B1 (水工学), 第 68 巻, pp.I_475-I_480, 2012.

8) Teuling, A.J., Lehner, I., Kirchner, J.W. and Seneviratne, S.I.: Catchments as simple dynamical systems: Experience from a Swiss prealpine catchment, Water Resour. Res., Vol.46, W10502, doi: 10.1029/2009WR008777, 2010.

9) Birkel, C., Soulsby, C. and Tetzlaff, D.: Modelling catchment-scale water storage dynamics: reconciling dynamic storage with tracerinferred passive storage, Hydrol. Process., Vol.25, pp.3924-3936, doi: 10.1002/hyp.8201, 2011.

10) Krakauer, N.Y. and Temimi, M.: Stream recession curves and storage variability in small watershed, Hydrol. Earth Syst. Sci., Vol.15, pp.2377-2389, doi: 10.5194/hess-15-2377-2011.

11) McMillan, H.K., Clark, M.P., Bowden, W.B., Duncan, M., Woods, R.A.: Hydrological field data from a modeller's perspective: Part 1. Diagnostic tests for model structure, Hydrol. Process., Vol.25, pp.511-522, doi: 10.1002/hyp.7841, 2011.
12) Kobayashi, S. and Yokoo, Y.: Estimating watershed-scale storage changes from hourly discharge date in mountainous humid watersheds: toward a new way of dominant process modeling, Hydrol. Res. Lett., Vol.7, pp.97-103, 2013, doi: 10.3178/hrl.7.97.

13) 日野幹雄, 長谷部正彦: フィルター分離AR法による非線 形流出系の同定と予測 (時間単位), 土木学会論文報告集, 第324 号, pp.83-94, 1982.

14) Yokoo, Y., Wattanakarn, C., Wattanakarn, S., Semcharoen, V., Promasakha na Sakolnakhon, K., and Soralump, S.: Storage under the 2011 Chao Phraya river flood: An interpretation of watershedscale storage changes at two neighboring mountainous watersheds in northern Thailand, Hydrol. Res. Lett., 8, 1-8, doi: 10.3178/hrl.8.1, 2014.

15) 小林秀平, 横尾善之: 土㙵雨量指数と流域スケールの雨水 貯留量の推定值との関係, 土木学会論文集 B1 (水工学), Vol.70, No,4, I_349-I_354, 2014.

16) 西山光, 横尾善之: 降雨流出過程の地域性に関する研究, 東北地域災害科学研究, 第49巻, pp.145-150, 2013.

17) Brutsaert, W. and Nieber, J.: Regionalized Drought Flow Hydrographs From a Mature Glaciated Plateau, Water Resour. Res., Vol.13, pp.637-643, doi: 10.1029/WR013i003p00637, 1977.

18) Ishihara, Y. and Kobatake, S.: Runoff Model for Flood Forecasting, Bulletin of the Disaster Prevention Research Institute, Vol.29, pp27-43, 1979.

19) 岡田憲治, 牧原康隆, 新保明彦, 永田和彦, 国次雅司, 斉 藤清: 土壤雨量指数, 天気, Vol.48, pp.349-356, 2001.

20) Milly, P.C.D.: Climate, interseasonal storage of soil water, and the annual water balance, Adv. Water Resour, Vol.17, pp.19-24, 1994.

21) Bishop, K., Seibert, J., Nyberg, L., and Rodhe, A.: Water storage in a till catchment. II: Implications of transmissivity feedback for flow paths and turnover times, Hydrol. Process., Vol.25, pp.39503959, doi: 10.1002/hyp.8355, 2011.

22) Soulsby, C., Piegat, K., Seibert, J. and Tetzlaff, D.: Catchmentscale estimates of flow path partitioning and water storage based on transit time and runoff modeling, Hydrol. Process., Vol.25, pp.3960-3976, doi: 10.1002/hyp.8324, 2011.

23) MacDonald, A.M., Bonsor, H.C., Dochartaigh, B.E.O., and Taylor, R.G.: Quantitative maps of groundwater resources in Africa, Environ. Res. Lett. Vo.7, 024009, doi: 10.1088/17489326/7/2/024009, 2012.

24) Sivakumar, B and Berndtsson R. (eds): Advances in Data-Based Approaches for Hydrologic Modeling and Forecasting, World Scientific, Singapore, 544pp, 2010.

25) Sivakumar, B.: Dominant processes concept in hydrology: moving forward, Hydrol. Process., Vol.18,pp. 2349-2353, 2004.

(2014. 9. 30受付) 